\title{
VIEWPOINT
}

\section{Badger culling does not control cattle TB}

\author{
M. HANCOX \\ 17 Nouncells Cross, Stroud, Glos. GL5 1PT, UK
}

(Revised MS received 4 March 2004)

A somewhat unpredicted effect of the 2001 Foot and Mouth crisis, has been to "derail the TB control programme both as regards cattle measures and the badger culling trial' (EFRA 2003). Sadly, cattle TB is now out of control, rising by c. $20 \%$ a year, and back to 1960 s levels. Unfortunately attention has focused to such an extent on badgers that many now seemingly do not understand how TB works in cattle and why annual testing and movement bans are the answer: they brought cattle TB down to tiny southwest hot-spots by the mid-1970s without any badger culling (Hancox 2000, 2002, 2003).

The value of badger culling has been variously criticized: as a waste of money because it doesn't work (Dunnet et al. 1986; Hancox 1999); because neither Professor Krebs nor Professor Bourne could demonstrate any impact (EFRA 2003 Ev. 40); or because they may disrupt populations and increase the risk to cattle (even though it is unknown how badgers might give cattle a respiratory lung infection; Delahay et al. 2003).

The surprise abandonment of the badger culling in reactive trial areas, i.e. in response to cattle herd TB outbreaks last November, claimed a consistent above-expectation incidence of cattle TB of $27 \%$, proving a badger/cattle link, perhaps via a perturbation effect (Donnelly et al. 2003). However, do these views stand up to scrutiny?

(1) Reactive culls were of low priority, so between 1999 and January 2001 only 319 badgers had been culled in 3 reactive areas (Table 1). By January 2003 only 672 in 6 of the 10 areas, and only 3 of more than 100 badgers. So most of the 2047 culls were in 2003 (May-September), i.e. the last 5 months of the 5 years. Since cattle TB takes months to develop, these final culls can hardly have been reflected in cattle TB. And in the figure 2 explanation of over-expectation results it is odd that the lowest cull of 94 in area I sits by the highest figure of 435 in F (Donnelly et al. 2003).

(2) Using DEFRAs own data, the 2047 might have comprised $25 \%$ infected $=500$; of which a third
Table 1. Numbers of badgers culled in reactive trial areas between 1999-2003

\begin{tabular}{|c|c|c|c|}
\hline \multirow[b]{2}{*}{ Triplet area } & \multicolumn{3}{|c|}{ No. of badgers } \\
\hline & $\begin{array}{c}\text { January } \\
2001\end{array}$ & $\begin{array}{c}\text { January } \\
2003\end{array}$ & $\begin{array}{c}\text { September } \\
2003\end{array}$ \\
\hline $\begin{array}{l}\text { A Gloucestershire/ } \\
\text { Herefordshire } \\
\text { (Blaisdon) }\end{array}$ & 34 & 34 & 117 \\
\hline $\begin{array}{l}\text { B Devon/Cornwall } \\
\text { (Hartland) }\end{array}$ & 107 & 165 & 301 \\
\hline $\begin{array}{l}\text { C East Cornwall } \\
\text { (Otterham) }\end{array}$ & 178 & 206 & 394 \\
\hline $\begin{array}{l}\text { D East Herefordshire } \\
\text { (Puddlestone) }\end{array}$ & - & - & 122 \\
\hline $\begin{array}{l}\text { E North Wiltshire } \\
\text { (Cold Ashton) }\end{array}$ & - & 56 & 169 \\
\hline $\begin{array}{l}\text { F West Cornwall } \\
\text { (Stithians) }\end{array}$ & - & 62 & 435 \\
\hline $\begin{array}{l}\text { G Staffordshire/ } \\
\text { Derbyshire } \\
\text { (Nettley Knowle) }\end{array}$ & - & 149 & 256 \\
\hline $\begin{array}{l}\text { H Devon/Somerset } \\
\text { (Brendon Hills) }\end{array}$ & - & - & 159 \\
\hline $\begin{array}{l}\text { I Gloucestershire } \\
\text { (Alderton) }\end{array}$ & - & - & 94 \\
\hline J Devon (Cadbury) & - & - & - \\
\hline Total & 319 & 672 & 2047 \\
\hline
\end{tabular}

Based on Ev. 48 in EFRA Report, and Donnelly et al. (2003).

might be infectious i.e. capable of passing on $\mathrm{TB}=$ 150 . Which in $900 \mathrm{~km}^{2}$, or 1 per $6 \mathrm{~km}^{2}$, admittedly more closely linked to the herd TB outbreaks reactively, can scarcely have been the causal factor claimed.

The higher incidence is hardly surprising since by definition reactive areas are TB hotspots, and despite clever statistics these results do not prove anything. Ending costly pointless culls 'scientifically' was a political decision (Hancox 1999). 


\section{REFERENCES}

Delahay, R. J., Wilson, G., Rogers, L. M. \& Cheeseman, C. L. (2003). Bovine tuberculosis in badgers: can culling control the disease? In Conservation and Conflict, Mammals and Farming in Britain (Eds F. Tattersall \& W. Manley), pp. 165-171. London: Linnean Society.

Donnelly, C. A., Woodroffe, R., Cox, D. R., Bourne, J., Gettinby, G., Le Fevre, A. M., McInerney, J. P. \& Morrisson, W. I. (2003). Impact of localized badger culling on tuberculosis incidence in British cattle. Nature 426, 834-837.

Dunnet, G. M., Jones, D. M. \& McInerney, J. P. (1986). Badgers and Bovine Tuberculosis. London: HMSO.
EFRA (2003). Badgers and Bovine TB. House of Commons, Environment, Food and Rural Affairs Committee, HC 432. London: The Stationery Office.

Hancox, M. (1999). Badger TB in perspective. Animal Welfare 8, 94; also 4, 260.

Hancox, M. (2000). Cattle tuberculosis schemes: control or eradication? Letters Applied Microbiology 31, 87-93.

Hancox, M. (2002). The great badgers and bovine TB debate. Journal of Agricultural Science, Cambridge 139, 223-226.

Hancox, M. (2003). Cattle TB crisis: cause and cure? In EFRA, Badgers and Bovine TB. HC 432. www. publications.parliament.uk. Appendices 6 \& 7 . 